\title{
An Analysis of Socio-Ecological Impact of Unauthorized Gold Mining in West Dumoga, Bolaang Mongondow District, North Sulawesi Province
}

\author{
Atika Marazman ${ }^{1}$, Tania F. Mokoagow ${ }^{2}$ \\ $\frac{\text { tikamarzaman@gmail.com\} }}{\text { Universitas Gorontalo }}$
}

\begin{abstract}
Unlicensed Gold Mining (Penambangan EmasTanpa Izin - PETI) is a mining business undertaken by an individual, or a group of people, or a legal entity incorporated in its operation without licenses and government agencies in accordance with applicable laws and regulations. PETI activities that do not follow the correct mining rules, have resulted in environmental damage, waste of mineral resources, and mine accidents. Besides that, PETI not only causes the potential revenue to decrease, but also the state/government must spend enormous funds to repair environmental damage. This research takes place in West Dumoga, Bolaang Mongondow District, North Sulawesi Province which has several points which become the location of unlicensed gold mining (PETI). In accordance with the objectives to be achieved, this research using descriptive qualitative research method. The results of this study are expected to provide a comprehensive argument of the phenomenon of PETI in West Dumoga, Bolaang Mongondow District, North Sulawesi Province along with the ecological, economic and social impacts. Furthermore, the results of this study is expected to be a contribution of thought to the Government of Bolaang Mongondow District in policy making and solving problems of PETI. This research is also expected to be a source of reference for related parties and society in general.
\end{abstract}

Keywords: Gold Mining, Socio-Ecological Impact, Market

\section{Introduction}

The phenomenon of the development of the mining industry in Indonesia is still a polemic until now. The fact is that mining in Indonesia mostly still causes various conflicts ranging from political, social, cultural to economic conflicts. Conflict in the mining area was triggered by two basic changes namely economic conditions marked by the deterioration of the welfare of some Indonesian people and the weak legal conditions in terms of enforcement resulting in many gaps of capital holders using the people to gain access to the mineral resources [1]-[3].

Conflict in the mining area usually involves many intellectual actors and also capital holders. When examined, it can be said that mining conflicts can occur at two levels, namely the macro level and micro level. At the macro level, conflicts occur at a wider horizontal scope, including conflicts between government agencies, forestry institutions and NGOs with central and regional governments. At the micro level, conflicts occur between the local 
community and the company and/or the local government, or with speculators and officials [4].

Unlicensed Mining (PETI) is a mining business carried out by an individual, a group of people, or a legal foundation company whose operations do not have permits and government agencies in accordance with the prevailing laws and regulations. According to Act No. 11 of 1967, the definition of community mining is a mining business of excavated materials from all classes a, b and c as intended in Article 3 paragraph (1) carried out by local people on a small scale or in mutual cooperation using simple tools for self- employment.

PETI begins with the presence of traditional miners, which later worsen due to poverty, limited employment and business opportunities. On the other hand PETI then creates disharmony between the company and the local community. In addition, weaknesses in law enforcement and legislation that impose mining by the people also contribute to the rise of PETI.

In reality, PETI activities that do not follow the correct mining principles have resulted in environmental damage, waste of mineral resources, and mining accidents. Besides that PETI not only causes the potential of revenue to decrease, but also the state/government must spend a very large amount of money to repair the environmental damages. Another thing that needs to be observed is that PETI is generally close toa culture of violence/thuggery, prostitution and gambling. Social turmoil, both between official companies and PETI perpetrators as well as among PETI perpetrators themselves is another negative impact due to the existence of PETI. Therefore, through the Republic of Indonesia Presidential Instruction NO. 3 of 2000, instructed ministers, attorney general, police chief, governors and regents/mayors to make efforts to deal with problems and control and stop all forms of mining activities without permits, functionally and comprehensively according to their respective duties and authorities.

Act No. 4 of 2009 Article 8 states the authority of district/city governments in the management of mineral and coal mining, and the making of regional laws and regulations, and the granting of Mining License and Permit for Space Utilization, guidance, community conflict resolution, and supervision of mining businesses in the district/city and/or sea area is up to 4 (four) miles. So based on the elaboration of the Act, the Regional Government must provide community conflict guidance due to the emergence of PETI.

North Sulawesi Province has several points in areas containing minerals. One of the minerals found in North Sulawesi Province is gold. The area in the province of North Sulawesi is rich in gold mining, namely Bolaang Mongondow Regency. In Bolaang Mongondow Regency there are several locations that have the potential to contain gold. One of them is the location of gold mining activities located in West Dumoga District. The existence of gold mine in West Dumoga Subdistrict has a positive impact and a negative impact on the community in West Dumoga District and neighboring sub-districts that come to try their fate at the mining site. The positive impact since the discovery of the mining site is the employment opportunities for the people of West Dumoga District are wide open. Not only people in Dumoga Barat sub-district, even people from neighboring SubDistricts/Villages and other regions felt the positive impact.

Although it is believed to have a positive impact on the economy of the community, in reality mining in the West Dumonga region brings negative effects that cannot be avoided. This is evident from the environmental damage caused. At present in the area around the mine has been severely damaged due to land clearing by haphazard felling of trees. Not to mention the mining waste that is not managed properly. So it is very dangerous for the surrounding community. 
In addition to the ecological impact, there are also social conflicts and clashes that occur between people in the mining area. In the mining area, there are frequent clashes between the miners who even cause casualties. The cause of the emergence of conflict is largely motivated by economic factors where the miners compete for mining areas. The clash also arises between miners and the surrounding community, where the community rejects the existence of the mine because of the ecological problems they have experienced.

Judging from the same case, PETI conflict also occurred in Petapahan Village, Gunung Toar District, Kuantan Singingi Regency [5]. In his research, Al Zuhri explained that the PETI conflict often happens both direct violence and indirect violence, because of the many interests upon the mine site. The difference in interests later gave birth to conflict in the midst of the Petapahan Village community. As a form of solution, the community and NGOs work hand in hand with the government to approach it by providing counseling to workers, employers and the public on environmental awareness, as well as the impacts that occur due to the activities of PETI itself.

Based on the facts above, this research then raised the illegal mining phenomenon as an object of research. This research will explore further the social and ecological impacts caused by PETI on the citizens of West Dumonga.

\section{Method}

\subsection{Types of research}

In accordance with the objectives to be achieved, this research is categorized as qualitative research using descriptive research. This study will study the social and ecological impacts caused by community gold mining in West Dumoga District, Bolaang Mongondow Regency.

\subsection{Data source}

\section{Primary Data}

Primary data is data obtained directly from the original source or from the respondent through an interview sheet.

2.Secondary data

Secondary data is the source of data obtained through intermediary media or indirectly in the form of books, records, existing evidence, or archives both published and not publicly published.

\subsection{Method of Data Collection \\ 1.Observation}

Observation techniques are carried out by researchers to observe closely the phenomena associated with the analysis of the social and ecological impacts of community gold mining conflicts in West Dumoga District, Bolaang Mongondow Regency. Through this observation technique, the researcher directly obseving to the research location to identify the nature and circumstances of the research location. The aim is to observe and systematically record problems related to the research topic.

\section{Documentation}

Documentation is done bycollecting data that is relevant to the topic through written documents. These documents are in the form of the district demographics, employees, number of people, and related reports.

3.Interview 
Interviews are conducted to collect information directly from respondents. Some respondents in the study were the mining actors, NGOs, local governments and communities in the mining site.

\section{Result and Discussion}

The total area of West Dumoga Districtr eaches 37,544 hectares or 10.71 percent of the area of Bolaang Mongondow Regency. In 2008,West Dumoga District had 14 villages, 12 of which had definitive status, while the other 2 were still in preparatory villages, Ibolian I and KosioTimur. In 2011, West Dumoga District was divided into two subdistricts by forming Kecamatan and Central Dumonga. After this division, West Dumoga District has 11 villages.

The trading center in this District is in the Doloduo Village and Kosio Village. Both of these villages experienced rapid development due to being crossed by motorized vehicles through Jalan AKD (Amurang-Kotamobagu-Doloduo). The main source of income for the community is farming or more than 90 percent of them work in the agricultural sector. But there is no doubt that there are still around 2,580 of them who work as agricultural laborers with commodities mainly rice crops.

As a fertile region, this district has always been the destination of transmigrants, especially from Bali island. Since 1963 the transmigrants have been placed in the village of WerdhiAgung with the number at that time as many as 349 families or 1,549 people.

As a developing region, the annual population growth rate is quite low, on average only 1.08 percent. In 2003 the population was still 23,786 people, in 2008 there were 27,753 people, of which males were 14,568 and females numbered 13,185 with a sex ratio of 110.49 so that within a period of five years there had been an increase of 3,456 inhabitants. While the number of householdsin the same year (2008) had reached 6,895 RTs and on average had 4.03 household members.

Table 1The population of West Dumoga District by sex

\begin{tabular}{cll}
\hline No & Sex & Population \\
\hline 1. & Male & 14.568 \\
2. & Female & 13.185 \\
& Total & 27.753 \\
\hline
\end{tabular}

Source: West DumogaDistrict office

\subsection{The Ecological Impact of PETI}

In many mining cases, the effects of environmental damage often occur. In the case of PETI in the District of West Dumongga, the impact of environmental damage was felt by the surrounding community. According to the Secretary of Dumoga District, the gold mine was in the area of Nani Wartabone Protected Forest precisely in the North Toraut Village. This mine has been used as a source of the community livelihood. In reality, it cannot be denied that the presence of this mining site has implications for the condition of the protected forests. Illegal logging is often carried out to expand the mining area.

This environmentally harmful mining exploration process is certainly not through the applicable mechanisms and procedures. Based on the interviews with local governments, the process of land clearing was not reported to the local government in both the district and the 
village. This is because this mining is indeed carried out haphazardly and does not follow the rules so that if it is reported, it will be potentially rejected by the government.

The mining emerged without a permit from the North Toraut Village Chief in 1986, but began to stir up and known by the community in 1992. The name of the first mine site was Karamba, then Teluk Edisante. The interviews show that the ecological impact is very much felt by the community. Not only does it damage the protected forest area, environmental damage is also exacerbated by the presence of mine waste that is dumped recklessly and close to the residential areas. Residents around the mining site who work as farmers complained about waste that pollutes water and soil which then damages their agricultural crops. In addition, the mine waste also pollutes the water used by residents for daily use.

The government certainly plays an important role in the mine management process. For this reason, the researchers interviewed the district government, and the village government, as well as the community leaders regarding their response to the impact of the mining damage caused by PETI in the West Dumonga District. Broadly speaking, it was found that the general public still lacked of understanding about the environmental impacts caused by the mining activities. On the other hand they have no other choices in regards to the removal of mining waste because of their limited knowledge and lack of understanding of technology in waste management.

On the other hand, the government in fact still lacks of campaigning for environmental conservation activities which certainly does not build public awareness of the impact of environmental damage caused by mining activities. Communities around the mining site themselves are expecting the role of the government, especially the relevant agencies to provide socialization and understanding of environmental pollution. The results of the field research found that the local government of Bolaang Mongondow was not involved or went directly to the mining location to give them an understanding of how to protect the environment. The mining community should be given an understanding that the mine must pay attention to the long-term effects of life around the mining site.

\subsection{Social Impact - Conflict Due to PETI}

One of the most significant impacts in unlicensed mining is the emergence of social conflict. Conflicts do not only occur between communities, but also occur between the community and the government as well as between the community and the private sector. The emergence of social conflict certainly has a negative impact on the social system within the society, in which the conflicted conflict will not be integrated with each other which will then affect to the damage of community governance both economically and politically.

Mining conflicts that have occurred in the last six years in West Dumonga District are between Doloduo village and Ikhwan village. The conflict occurred because of a dispute between the group of miners at the mining site, which then escalated into the village level. The conflict between the two villages also later involved police officers. Although the conflict can be resolved in family way which is mediated by the Bolaang Mongondow Police Cheif, the area still has a great potential for conflict. In December 2017 the conflict broke out again between the Ikhwan village and the Uuwan village, namely the struggle for a location named EdySante. With the conflict over the location, the Chief of Bolaang Mongondow Police Chief AKBP Gani F Sihaan S.Ik.MH, took the decision to temporarily close the location before a decision was made from the mediation carried out by the Bolaang Mongondow police station on both sides

Even though there is always a conflict, people still carry out their activities as miners. This was done because almost all of the residents of the West Dumoga District had livelihoods as 
miners. It is undeniable that the economic conditions pressured the community to keep opening new mining site even though the potential for conflict was very large.

In order to create a good, clean government and a society that lives peacefully, the government then takes quick steps to deal with things that cause the conflict. According to the Dumoga district secretary, the government has carried out the deliberation steps by calling on the officers from the two village whose communities were involved in the conflict and then conducting guidance and explanation in accordance with the regulations related to mining. This was further explained by the Village Head of Doloduo 1, that the steps taken by the District Government were to bring the community from the two conflicted villages and provide guidance.

In the process of conflict resolution, heart to heart discussion is a path that is often taken. Both sub-district and village governments do not dare to directly intervene in mining management because it is feared that it will lead to a greater conflict. This was stated by the village head (Sangadi) of North Toraut, that if the government took over the people's gold mines, the government must be able to bring in POLRI/TNI personnel because of course there would be prolonged conflict and clashes between the government and the miners. So the best way that can be done by the government is by preparing a series of strategic rules and policies in managing the people's mine and conducting guidance to the community, especially miners.

In addition, activities that can be carried out by the government as an alternative solution to solve the conflict are by coordinating community empowerment activities. Community empowerment is a continuous activity. Through this activity the community will participate directly in the mining management process in accordance with the rules set by the government. With this involvement the community is also expected to build kinship relationships so that they can work together and minimize the potential for conflict.

The goal to be achieved through community empowerment efforts related to gold mining, is that the community is independent, self-sufficient, capable of adopting innovation and having a sustainable mindset of mine management. The factor of increasing community empowerment aims to increase the potential of the community and the quality of human resources through formal and non-formal education. Knowledge of sustainable gold mining management is very important both for the administration of government, especially for the mining community.

Article 33 paragraph (3) of the 1945 Constitution above implies that the right of state control contains the authority to regulate, manage, and supervise the management or exploitation of quarrying materials, as well as contain the obligation to use it as much as possible for the prosperity of the people. The explanation of the above constitution is enough to explain that the entire contents and wealth of the earth are state property and are intended for the welfare of the people, including the people's gold mines in the West Dumoga District. The existence of the gold mine has changed the pattern of life of the people around the mine, especially in relation to economic improvement and welfare improvement. For this reason, it is necessary to have the role of the local government and village government in regulating and controlling gold mining activities so as to maximize the potential they have.

\section{Conclusion}

Based on the description above, the researcher draws conclusions as follows:

1. Unlicensed gold mining in West Dumonga District has had an impact on changes in the economic, as well as on social conditions of the community and has an impact on significant ecological damage. 
2. Handling the ecological impacts caused by PETI in the District of West Dumonga, coordination and communication between the district government and village government is needed in the formulation of policies concerning the arrangement of the environment around the mining site. Likewise with the social conflicts that occur. Government intervention in conflict resolution and community involvement is needed to rebuild safe and peaceful social conditions.

Conclusion should answer the objectives of the research and the research discoveries. The concluding remark should not contain only the repetition of the results and discussions or abstract. You should also suggest future research and point out those that are underway.

\section{References}

[1] B. Denar, "Polemik Pertambangan Di Manggarai Barat Dan Relasinya Dengan Ajaran Sosial Gereja," SEPAKAT-Jurnal Pastor. Kateketik, vol. 1, no. 2, p. 32, 2015.

[2] D. Setiawan and R. T. Herman, "Re-Thinking Kebijakan Pembangunan dalam Perspektif Ekonomi Lokal: Studi Kasus Tambang Emas Batu Gosok-Labuan BajoNTT," Binus Bus. Rev., vol. 2, no. 1, pp. 466-476, 2011.

[3] R. Setyadiharja, "Problematika bauksit di tanah gurindam (analisis proses legislasi kebijakan tambang bauksit di kota tanjungpinang)," JIP (Jurnal Ilmu Pemerintahan) Kaji. Ilmu Pemerintah. dan Polit. Drh., vol. 1, no. 1, pp. 21-47, 2016.

[4] P. Radyan, "Konflik di Kawasan Pertambangan," 2012. .

[5] Al Zuhri, "Konflik Pertambangan Emas Tanpa Izin (PETI) Di Desa Petapahan Kecamatan Gunung Toar Kabupaten Kuantan Singingi," Jom FISIP V, vol. 2, no. 2, 2015. 